\section{Kastamonu Eğitim Dergisi Kastamonu Education Journal}

Mayıs 2019 Cilt:27 Sayı:3

kefdergi.kastamonu.edu.tr
Başvuru Tarihi/Received: 16.03 .2018

Kabul Tarihi/Accepted: 8.06.2018

DOI: $10.24106 /$ kefdergi.2826

\title{
Uzamsal Görselleştirme Testinin Geliştirilmesi: Geçerlik ve Güvenirlik Çalışmaları
}

\section{Development of Spatial Visualization Test: Validity and Reliability Studies}

\section{Öz}

\author{
Neşe DOKUMACI SÜTÇÜ1, Behçet ORAL ${ }^{2}$
}

Bu araşttrmada, uzamsal yeteneğin bileşenlerinden biri olan uzamsal görselleştirme becerisini ölçmek için çoktan seçmeli bir test geliştirmek amaçlanmıştır. Testin geliştirilme aşamasında, kapsam geçerliği için uzman görüşü alınmış ve testten altı madde çıkarılarak, 32 maddelik test geçerlik ve güvenirlik çalışmaları için yedinci sınıf öğrencilerine uygulanmıştır. Testin faktör yapısını belirlemek amacıyla maddeler arası Tetrakorik Korelasyon Matrisi üzerinden açımlayııı faktör analizi gerçekleştirilmiş ve bir madde testten çıkarılarak iki faktörlü bir yapı elde edilmiştir. Daha sonra testin iki faktörlü yapısının bir model olarak doğrulanıp doğrulanmadığını belirlemek için Asimptotik Kovaryans Matrisi ile Ağırlıklı En Küçük Kareler Yöntemi'nden yararlanılarak doğrulayıcı faktör analizi uygulanmıştır. İki madde testten çıkarılıp, kuramsal olarak birbirlerine yakın maddeler arasında modifikasyon yapıldıktan sonra, iki faktörlü yapının yeterli uyum indekslerine sahip olduğu görülmüştür. Kalan 29 madde için madde analizi yapılmış; testin farklı güçlük düzeylerine ve yüksek ayırt ediciliğe sahip maddelerden oluşan, orta güçlükte ve ayırt ediciliği yüksek bir test olduğu ortaya çıkmıştır. Yapılan güvenirlik çalışması ile de testin KR-20 iç tutarlılık açısından güvenilir olduğu tespit edilmiştir.

Anahtar Kelimeler: uzamsal yetenek, uzamsal görselleştirme, test geliştirme, geçerlik, güvenirlik

\section{Abstract}

In this study, it was aimed to develop a multiple choice test in order to measure about spatial visualization skills, which is one of the components of spatial ability. In the test development phase, after taking expert opinion for content validity, six items were removed from the test and the test with 32-item was applied to seventh-grade student for validity and reliability studies. In order to determine the factor structure of the test, explanatory factor analysis was performed via the Tetrachoric Correlation Matrix between the items and a two-factor structure was obtained by being removed the one item from the test. Afterwards, confirmatory factor analysis was applied by using the Asymptotic Covariance Matrix and the Weighted Least Squares Method in order to determine whether the two-factor structure of the test was confirmed as a model. After being removed of two items from the test and modifications were made between items close to each other theoretically, it was found that the two-factor structure had adequate fit indices. Item analysis was performed for the remaining 29 items; the test was found to be moderately difficult and highly distinctive which consists of items with different difficulty levels and highly distinctive. The test was found to be reliable in terms of KR-20 internal consistency with the reliability study that was done.

Keywords: spatial ability, spatial visualization, test development, validity, reliability

1. Dicle Üniversitesi, Eğitim Fakültesi, Matematik ve Fen Bilimleri Eğitimi Bölümü, Diyarbakır, Türkiye; https://orcid.org/0000-0003-3279-4194

2. Dicle Üniversitesi, Eğitim Fakültesi, Eğitim Bilimleri Eğitimi Bölümü, Diyarbakır,.Türkiye; https://orcid.org/0000-0002-6885-1683

Atıf / Citation: Dokumacı Sütçü, N., Oral, B. (2019).Uzamsal görselleştirme testinin geliştirilmesi: geçerlik ve güvenirlik çalışmaları. Kastamonu Education Journal, 27(3), 1179-1195. doi:10.24106/kefdergi.2826 


\section{Extended Summary}

Introduction: Spatial ability is the skill to create an image of the visual stimulus that we see around us in the mind and manipulate those images in the mind. When literature related to spatial ability is examined, although the researchers classify spatial ability in a wide variety of ways, it is seen that the spatial ability component on which most of the researchers agree is "spatial visualization". For this reason, spatial visualization is accepted as one of the most important subcomponents of spatial ability. There are many researches on spatial visualization that have been made on different disciplines and studied on different samples. However, it is noteworthy that some of the major spatial visualization tests have been used repeatedly. Furthermore among the tests in the literature, two or three dimensional spatial skills such as paper folding, mental integration, mental separation, and cube making are measured by different spatial visualization tests which are conformity with different class levels.Therefore, the aim of this research which is on the subject of spatial visualization skill is to develop a more comprehensive multiple-choice test that is conformity with seventh grade level and that measures two and three dimensional spatial visualization skills with the same test.

Method : The Spatial Visualization Test (SVT) consisted of 38 items with four alternatives at the first stage. After the expert opinion for content validity had been obtained, six items were removed from the test at the development phase of the test, and necessary corrections were made on the remaining items. In addition, the test was applied to three students in order to determine whether the test items were understandable for the students, and necessary corrections were made in places where the items were not understood. After the expert opinions had been received, the test consisting of 32 items was applied to the 301 seventh grade students who were studying in the central districts of Diyarbakır province in 2016-2017 educational years for validity and reliability studies. The answers of the students to the test were first recorded by using "Microsoft Office Excel" program as A, B, C, D. This data was then artificially converted into two discrete categorize in the way that the " 1 " for correctly answered items and " 0 " for wrongly answered and blank items. The scores that were obtained from the test were tested by using the "SPSS 21 " program whether they distribute normally. For this, histogram, normal $Q-Q$, detrended normal $Q-Q$, box-line graphs and kurtosis and skewness values were taken into consideration. After that, Exploratory Factor Analysis (EFA) was performed on the Tetrachoric Correlation Matrix between the items in order to determine the factor structures of the test. For this, "FACTOR 10.3.01" and "SPSS 21" programs were used. Confirmatory factor analysis (CFA) was applied by using the Asymptotic Covariance Matrix and the Weighted Least Squares Method in order to determine whether the factor structures that were obtained from the result of EFA were verified as a model. For this, "LISREL 8.54" program was used. After EFA and CFA, item analysis was carried out by using the "ITEMAN 3" program through the data that were processed as $A, B, C, D$, in order to present the findings related to difficulty level of items, distinctiveness and operability of distractors. The KR-20 (alpha), internal consistency reliability coefficient, was calculated by "ITEMAN 3" program in order to determine the reliability of the test.

Results: After having received the expert opinions, at first the EFA was done to determine the factor structures of the 32-item test which was applied to 301 students for validity and reliability studies. As a result of EFA, a two-factor structure "Two Dimensional Spatial Visualization" consisting of 15 items and "Three Dimensional Spatial Visualization" consisting of 16 items were obtained by excluding of the 6th item from the test. With the exclusion of the 6th item from the analysis, it was observed that the factor loadings of the remaining items changed between .43 and .72 for the first factor and between .44 and .68 for the second factor. Furthermore, it is seen that the explained variance ratios are $20.80 \%$ for the first factor, $15.42 \%$ for the second factor, and total variance is $36.22 \%$ for both factors. In order to determine whether the two-factor structure that was obtained from the result of AFA is verified as a model, the items ( 11 and 20 ) that were proposed to be connected with more than one item, which are theoretically close to each other were extracted from the test, and the modifications were made between the items ( 15 and 16, 24 and 25 and 30 to 32) close to each other theoretically. After the 11th and 20th items had been removed from the test and after the modifications had been done, it was seen that the two-factor structure obtained consisting of the remaining 29 items had sufficient fit index. ( $\chi 2 /$ sd:1.26, RMSEA:0.029, GFI:0.96, AGFI:0.95, SRMR: 0.074, NNFI:0.92, CFI:0.93). Material analysis was performed for the remaining 29 items; the test was found to be moderately difficult and highly distinctive which consists of items with different difficulty levels and highly distinctive. The KR-20 internal consistency coefficient was calculated to be .78 for the first factor consisting of 14 items, and .78 for the second factor consisting of 15 items. The KR-20 internal consistency coefficient belonging to the entire test was calculated as .78. It was put forth with this study that the Spatial Visualization Test consisting of 29 items was a valid and reliable test with exploratory factor analysis, confirmatory factor analysis, item analysis and reliability studies after the expert opinion for the content validity had been obtained. Based on the test which was developed in the scope of the research, it is suggested that researchers should develop comprehensive tests which accord with different class levels and which take different components of spatial ability into consideration.

| Kastamonu Eğitim Dergisi, 27(3), 2019| 


\section{Giriş}

Uzamsal yeteneğin ne olduğunu, insan akılına nasıl katkıda bulunduğunu, diğer faktörler veya değişkenleri etkileyip etkileyemediğini belirlemek için, neredeyse her çalışma alanı ile çok sayıda araştırma yapılmıştır (Hartman ve Bertoline, 2005). Araştırmalar, ilk olarak 1880'li yılların başında Sir Francis Galton'un zihinsel imgelerle ilgili çalışmaları ile başlamıştır. O zamandan beri, araştrrmacılar uzamsal yeteneği çeşitli şekillerde tanımlamış, uzamsal yeteneğin bileşenleri üzerinde tartsşmış ve bu yeteneği ölçmek için çeşitli yöntemler geliştirmişlerdir (Mohler, 2006).

Uzamsal yeteneği tanımlamaya çalışan ilk araştırmacılardan biri olan Kelley (1928) uzamsal yeteneği "şekillerin zihinsel manipülasyonu" olarak tanımlamıştır (Akt: McGee, 1979). Diğer araştırmacılardan Thurstone (1944) uzamsal yeteneği "düşünceler, sözlü kelimeler veya yazılı talimatların zihinde bir görüntüsünü tutma ve bunları manipüle etme becerisi" (Akt: Lord ve Rupert, 1995); Clements ve Battista (1992) "uzamsal nesneler, ilişkiler ve dönüşümler için zihinsel temsillerin oluşturulduğu ve manipüle edildiği bilişsel süreçler dizisi"; Olkun ve Altun (2003) ise "nesnelere ait görüntüler üzerinde zihinsel oynamalar yapabilme yeteneği" olarak tanımlamışlardır.

Uzamsal yetenek insanların, uzaydaki diğer nesnelere göre konumlarını belirlemelerine ve hareketli bir nesnenin yolunu tahmin etmelerine olanak sağlar (Freina ve Ott, 2014). İnsanlar her gün bu yeteneğini kullanmaktadırlar. Bu yetenek; yazılı bir cümleyi veya sözlü kelimeyi hayal ettiğinde, bir fikri formüle ettiğinde, bir stratejinin veya bir olayın sonucunu öngördüğünde, bir şeyi planlarken veya tasarlarken (Lord ve Rupert, 1995), mobilyaları monte ederken, gazetelerdeki grafikleri incelerken, bulunduğumuz yeri tayin ederken, harita yardımıyla yönümüzü bulmaya çalışırken (Jirout ve Newcombe, 2014) kullanılmaktadır. Bununla birlikte uzamsal yetenek; akademik başarı, özellikle de matematik ve geometri başarısıyla yakından ilişkilidir (Holzinger ve Swineford, 1946). Clements (1998), uzamsal yeteneğin matematik başarısı ile ilişkili olduğunu dolayısıyla matematik ve geometrinin birçok konusunu öğrenmede uzamsal yeteneğin önemli olduğunu ifade etmiştir. Dahası nedenini tam olarak bilmemekle birlikte, güçlü uzamsal yeteneğe sahip çocukların matematikte daha başarılı olduğunu da ilave etmiştir. Clements ve Sarama (2011) uzamsal yeteneğin, matematiksel beceriye katkıda bulunan önemli bir insani yetenek olduğuna dikkat çekmişlerdir. Friedman (1995) 75 araşttrmayı içeren bir meta-analiz çalışmasında, uzamsal ve matematiksel yetenekler arasında orta düzeyde, pozitif bir ilişki olduğunu, bu sonucun da uzamsal ve matematiksel yetenekler arasında önemli bir ilişkinin varlığını ortaya çıkardığını ifade etmiştir. Hatta Mix ve Cheng (2012) uzamsal yetenek ile matematik arasındaki ilişkinin yüksek düzeyde olduğunu bu nedenle uzamsal yetenek ile matematiğin ilişkili olup olmadıkları sorusunun mantıklı olmadığını belirtmişlerdir.

Günlük hayatta birçok görevi başarmada olduğu gibi başta matematik ve geometri olmak üzere birçok disiplinle de pozitif ilişki içerisinde olan uzamsal yetenek tek boyutlu ve değişmez özellikte değil, birbirleriyle ilişkili olan ve bir kişinin yaşamı boyunca geliştirilebilen alt becerilerden oluşmaktadır (Shamsuddin ve Din, 2016). Uzamsal yeteneğe dair alt becerilerin sayısı ve anlamları konusunda araştırmacılar arasında çeşitli görüşler vardır. Örneğin; McGee (1979) uzamsal yeteneği "uzamsal görselleştirme" ve "uzamsal yönelim" şeklinde iki bileşende ele alırken; Lohman (1979) uzamsal yetenek için "uzamsal görselleştirme", "uzamsal yönelim" ve "uzamsal ilişkiler" bileşenlerini kapsayan üç faktörlü bir model önermiştir. Pellegrino, Alderton ve Shute (1984) yapmış oldukları çalışmada uzamsal yeteneği "uzamsal görselleştirme" ve "uzamsal ilişkiler" olarak iki bileşene; Linn ve Petersen (1985) yaptıkları meta-analiz çalışması sonucuna göre "uzamsal algı", "zihinde döndürme" ve "uzamsal görselleştirme" olmak üzere üç bileşene; Gorska, Sorby ve Leopol (1998) "uzamsal görselleştirme", "zihinde döndürme", "uzamsal yönelim", "uzamsal algı", "uzamsal bağıntılar" olmak üzere beş alt bileşene ayırmışlardır. Uzamsal yetenek ile ilgili literatür incelendiğinde, araştırmacıların uzamsal yeteneği çok çeşitli şekillerde sınıflandırmalarına rağmen çoğu araştırmacının hemfikir oldukları uzamsal yetenek bileşeninin "uzamsal görselleştirme" olduğu görülmektedir. Uzamsal yetenek gibi uzamsal görselleştirme bileşeni de farklı araştirmacılar tarafindan farklı şekillerde tanımlanmaktadır. Uzamsal görselleştirmeyi, McGee (1979) "resimsel olarak sunulan uyarıcı bir nesneyi zihinde manipüle etme, döndürme, bükme veya tersine çevirme becerisi", Pellegrino vd. (1984) "nispeten hız gerektirmeyen ve karmaşık olan görevler", Linn ve Petersen (1985), "uzamsal olarak sunulan bilgilerin karmaşık, çok basamaklı manipülasyonlarını içeren görevler", Pittalis ve Christou (2010) "üç boyutlu bir uzayda hayali hareketleri ya da hayal gücündeki nesneleri idare etme kabiliyeti" olarak tanımlamışlardır.

Uzamsal görselleştirme becerisi ile ilgili yapılan araştrrmalar (Battista, 1990; Fennema ve Sherman, 1977; Turğut ve Yılmaz, 2012) öğrencilerin uzamsal görselleştirme becerileri ile matematik başarıları arasında anlamlı, pozitif bir ilişkisi olduğunu göstermiştir. Yüksel ve Bülbül (2014) uzamsal görselleştirme becerisinin, matematik ve geometri derslerinin vazgeçilmez bir parçası olduğunu ifade etmişlerdir. Battista, Wheatley ve Talsma (1982) ile Fennema ve Sherman (1977) öğrencilerin daha iyi bir matematik başarı seviyesine ulaşmaları için hayal edebilmeleri ve görselleştirebilmeleri gerektiğini öne sürmüşlerdir. Shea, Lubinski ve Benbow (2001) ile Wei, Yuan, Chen ve Zhou (2012) ise bu durumun matematik yeteneklerini öngören uzamsal görselleştirme becerisi ile mümkün olabileceğini belirtmişlerdir. Uzamsal görselleştirme 
becerisi ile matematiksel düşünme arasındaki güçlü ilişkiden dolayı, öğrencilerin uzamsal görselleştirme beceri düzeylerinin ölçülmesi ve eksikliği durumda bu becerilerin geliştirilmesine ilişkin önlemler alınması önem taşımaktadır. Literatürde öğrencilerin uzamsal görselleştirme becerilerini ölçmek amacıyla geliştirilmiş testler mevcuttur. Aşağıda, bu testlerden literatürde en çok bilinenlere ait örnek verilmektedir.

Turğut (2015) uzamsal görselleştirme becerisinin Purdue Uzamsal Görselleştirme Testi (Görselleştirmeler); Lohman (1979) ise Kâğıt Katlama, Şekil Panosu, WAIS Blok Tasarımı, Gizli Şekiller, Kopyalama ve Yüzey Geliştirme gibi testlerle ölçüldüğü ifade etmiştir. Linn ve Petersen (1985) uzamsal görselleştirme becerisinin ölçülmesi için Gizli Şekiller, Gömülü Şekiller, Kâğıt Katlama, Şekil Panosu, Yüzey Geliştirme, Ayrımsal Yetenek (Uzay İlişkileri Alt Testi), Blok Tasarımı ve Guilford-Zimmerman Uzamsal Görselleştirme Testi gibi testlerin kullanıldığını belirtmişlerdir. Pellegrino vd. (1984) Şekil Panosu, Kâğıt Katlama ve Ayrımsal Yetenek Testlerinin; Miyake, Friedman, Rettinger, Shah ve Hegarty (2001) Kâğıt Katlama ve Ayrımsal Yetenek Testlerinin (Uzay İlişkileri Alt Testi); Alias, Black ve Gray (2002) Küp Yapımı Testi'nin uzamsal görselleştirme becerisinin belirlenmesi amacıyla kullanılabileceğini belirtmişlerdir. Martín-Gutiérrez, Saorín, Martín-Dorta ve Contero (2009) uzamsal görselleştirme bileşeninin Ayrımsal Yetenek (Uzay Illişkileri Alt Testi); Pittalis ve Christou (2010) ise Şekil Panosu, Yüzey Geliştirme ve Kâğıt Katlama Testleri ile ölçülebileceğini ifade etmişlerdir. Bu testlere, MGMP Uzamsal Görselleştirme Testi, Olkun'un (2003) geliştirmiş olduğu İki Boyutlu Geometride Uzamsal Görselleştirme Testi ve Yüksel ve Bülbül'ün (2014) geliştirmiş oldukları Uzamsal Görselleştirme Testi de örnek olarak verilebilir.

Minessota Şekil Panosu Testi, 1941 yılında Likert ve Quasha tarafindan geliştirilmiştir. Test, iki boyutlu şekillerin birleştirildikten sonraki yeni görüntüsünü seçenekler arasından bulmaya yönelik sorulardan oluşmaktadır. Testin kullanıldığı araşttrmalarda (Diehl, Piehl ve Ranney, 1996; McKeever ve Deyo, 1990; Pazzaglia ve De Beni, 2001; Petrusic, Varro ve Jamieson, 1978; Shute, Pellegrino, Hubert ve Reynolds, 1983), test üniversite öğrencilerine uygulanmıştr.

Gömülü Şekiller Testi, 1950 yılında Witkin tarafindan geliştirilmiştir. Testte basit şekiller karmaşık şekiller içinde gizli halde bulunmaktadır. Testte istenen ise verilen basit şekilleri karmaşık şekiller içinde bulmaktır. Bu testin kullanıldığı araştormalarda (Crandall ve Lacey, 1972; Weisz, O'neill ve O’neill, 1975) test ortaokul seviyesindeki öğrencilere uygulanmıştr.

Ayrımsal Yetenek Testi (Uzay Iliş̧kileri Alt Testi), 1974 yılında Bennett, Seashore, ve Wesman tarafindan geliştirilmiştir. Testte, iki boyutlu açık hali verilen üç boyutlu nesnelerin katlandığında nasıl göründüğünün seçenekler arasından belirlenmesine yönelik sorular bulunmaktadır. Testin kullanıldığı birçok araştırmada (Diehl vd., 1996; Glück, Dünser, Steinbügl ve Kaufmann, 2007; Fennema ve Sherman, 1977; Lorenz ve Neisser, 1985; Olkun vd., 2007; Yüksel ve Bülbül, 2014), test lise ya da üniversite öğrencilerine uygulanmıştır.

Purdue Uzamsal Görselleştirme Testi (Görselleştirmeler), 1976 yılında Guay tarafindan geliştirilmiştir. Test, iki boyutlu açık hali verilen üç boyutlu nesnelerin katlandığında ne şekilde göründüğüne yönelik sorulardan oluşmaktadır. Yapılan katlamalar ile oluşan üç boyutlu şeklin verilen seçenekler arasından seçilmesi istenmektedir. Bu testin kullanıldığı birçok araştırmada (Glück vd., 2007; Kösa, 2011; Sharobeam, 2016; Topaloğlu 2011; Turğut, Yenilmez ve Balbağ, 2017), test lise ya da üniversite öğrencilerine uygulanmıştır.

Kâğıt Katlama Testi, 1976 yılında Ekstrom, French ve Harman tarafindan geliştirilmiş ve 1996 yılında Delialioğlu tarafindan Türkçe'ye çevrilmiştir. Testte, çeşitli şekillerde katlandıktan sonra belirli yerlerinden delikler açılan bir kâğıdın açıldıktan sonraki halinin ne şekilde göründüğüne yönelik sorular bulunmaktadır. Kâğıdın açıldıktan sonraki şeklinin verilen seçenekler arasından seçilmesi istenmektedir. Bu testin kullanıldığı birçok araştırmada (Bulut ve Köroğlu, 2000; Delialioğlu, 1996; Gromko, 2004; Kayhan, 2005; Lord ve Rupert, 1995; Mayer ve Sims, 1994; Tekin, 2007, Turğut, 2010; Yurt ve Sünbül, 2010), test lise ya da üniversite öğrencilerine uygulanmıştır.

Yüzey Geliştirme Testi, 1976 yılında Ekstrom, French ve Harman tarafindan geliştirilmiş ve 1996 yılında Delialioğlu tarafindan Türkçe'ye çevrilmiştir. Testte, iki boyutlu açık hali verilen şeklin noktalı yerlerden katlandığında oluşan yeni şekli verilmektedir. Testte istenen ise katlamayı hayal ederek numaralı köşelerin hangi harflere denk geleceğinin bulunmasıdır. Bu testin kullanıldığı birçok araştırmada (Bulut ve Köroğlu, 2000; Colom, Contreras, Shih, ve Santacreu, 2003; Delialioğlu, 1996; Gromko, 2004; Kayhan, 2005; Tekin, 2007, Turğut, 2010), test lise ya da üniversite öğrencilerine uygulanmıştır.

MGMP Uzamsal Görselleştirme Testi, Middle Grades Mathematics Project kapsamında 1989 yılında Winter, Lappan, Fitzgerald ve Shroyer tarafindan ortaokul öğrencileri için geliştirilmiştir. 2007 yılında Turğut tarafindan Türkçe'ye çevrilmiştir. Testte genel olarak üç boyutlu cisimlerin herhangi bir yönden görüntüsü, küplerden yapılmış bir binada kaç küp kullanıldığı ve herhangi bir yönden görüntüsü verilmiş bir binanın zihinde canlandırılması ile ilgili soruları içermektedir. Bunun yanında binalara yeni küpler eklendiğinde, çıkarıldığında ya da iki parçadan oluşmuş şekillerin birleşmesiyle oluşacak binanın şeklinin hangisi olduğu gibi sorular da yer almaktadır. Bu test ortaokul öğrencilerinin uzamsal görselleştirme becerilerini ölçmek amacıyla geliştirilmiş olmasına rağmen Robichaux (2000)'un belirttiği gibi soruların çoğundaki şekiller karmaşık olduğundan dolayı bazı araştırmalarda (Akbay, 2015; Dursun, 2010; Erkek, Işıksal ve Çakıroğlu, 2017) lise ve üniversite öğrencilerine, bazı araştırmalarda (Turğut, 2007; Uzun, 2013; Gül, 2014) ortaokul öğrencilerine uygulanmıştr. 
Küp Yapımı Testi, 2002 yılında Alias, Black ve Gray tarafindan üniversite öğrencilerinin uzamsal görselleştirme becerilerini belirlemeye yönelik geliştirilmiştir. Test, her bir yüzeyinde farklı resimler bulunan açık haldeki bir küpün kapalı halinin seçeneklerden arasından belirlenmesini içermektedir.

îki Boyutlu Geometride Uzamsal Görselleştirme Testi, 2003 yılında Olkun tarafindan dördüncü ve beşinci sınıf öğrencilerinin iki boyutlu geometride uzamsal görselleştirme becerilerini ölçmek amacıyla geliştirilmiştir. Test görsel algı ile yapılabilecek sorulardan oluşmaktadır.

Uzamsal görselleştirme becerisini ölçmeye yönelik bir başka test, Yüksel ve Bülbül (2014) tarafindan matematiksel bağlam dâhil edilerek üniversite öğrencilerinin seviyelerine yönelik geliştirilmiştir. Testte açık halinde üzerinde şekiller bulunan bir küpün kapalı durumunda boş bırakılan herhangi bir yüzüne gelecek şeklin bulunması, kapalı hali verilen bir küpün açık halinin verilen seçeneklerden hangisi olamayacağının belirlenmesi, düzgün olmayan şekillerin katlanmasıyla oluşan şekillerin bulunması gibi sorulara yer verilmiştir.

Tablo 1'de uzamsal görselleştirme bileşenini ölçmek amacıyla hazırlanan testlere ait sorulara yer verilmiştir.

Tablo 1. Uzamsal görselleştirme becerisini ölçmeye yönelik örnek sorular

İlgili Testler

Likert ve Quasha (1941) tarafindan geliştirilen Minessota Şekil Panosu Testinde, iki boyutlu şekillerin bir araya getirildikten sonraki yeni görüntüsünün bulunması istenmektedir.

Witkin (1950) tarafindan geliştirilen Gömülü Şekiller Testinde, solda verilen basit şekilleri sağda verilen karmaşık şekiller içinden bulunması istenmektedir.

Bennett, Seashore, ve Wesman (1974) tarafindan geliştirilen Ayrımsal Yetenek Testinde (Uzay iliş̧ileri Alt Testi), iki boyutlu açık hali verilen üç boyutlu nesnelerin katlandığında nasıl göründüğü sorulmaktadır.

Guay (1976) tarafindan geliştirilen Purdue Uzamsal Görselleştirme Testinde (Görselleştirmeler), iki boyutlu açık hali verilen üç boyutlu nesnelerin tabanı taralı kısım olacak şekilde katlandıktan sonraki yeni görüntüsünün bulunması istenmektedir.

Ekstrom, French ve Harman (1976) tarafindan geliştirilen Kâğıt Katlama Testinde, çeşitli şekillerde katlandıktan sonra belirli yerlerinden delikler açılan bir kâğıdın açıldıktan sonraki halinin nasıl görüneceği sorulmaktadır.

Ekstrom, French ve Harman (1976) tarafindan geliştirilen Yüzey Geliştirme Testinde, iki boyutlu açık hali verilen şeklin noktalı yerlerden katlandığında oluşan yeni şeklinde rakamlara karşılık gelen harflerin bulunması istenmektedir.
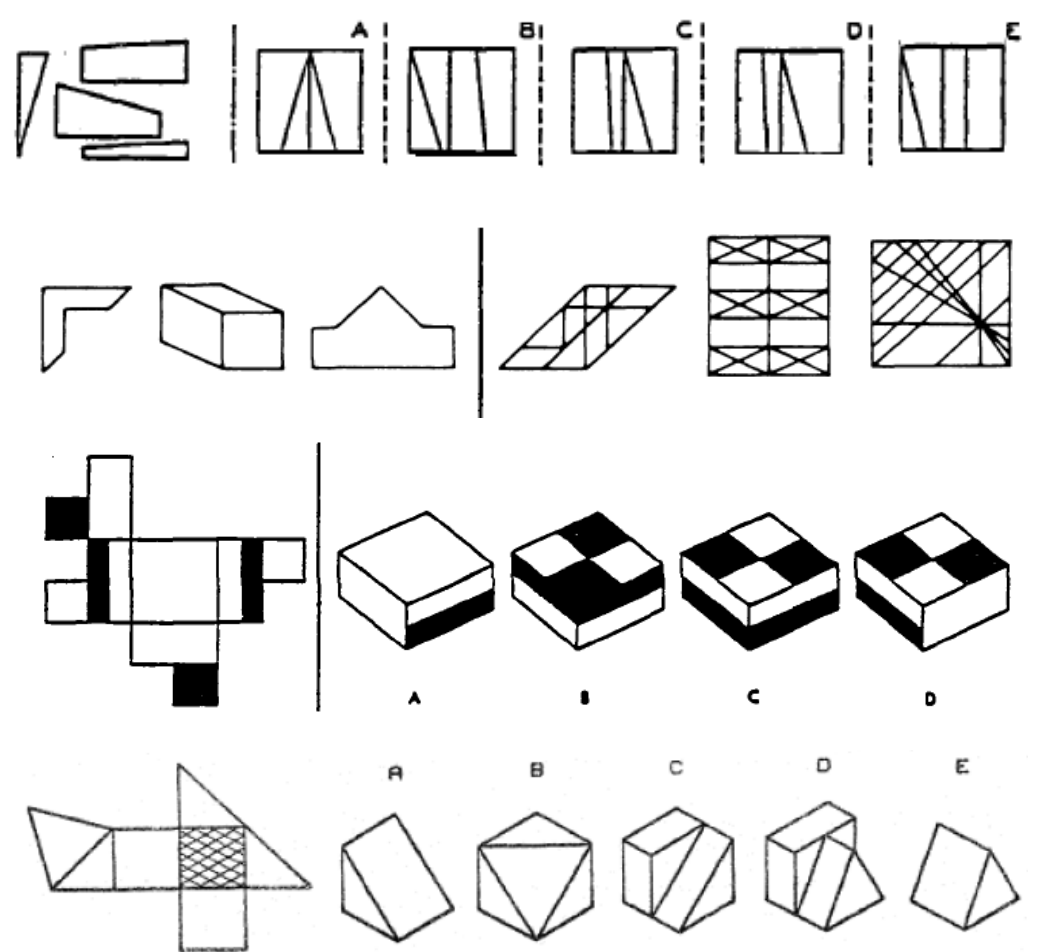

E.
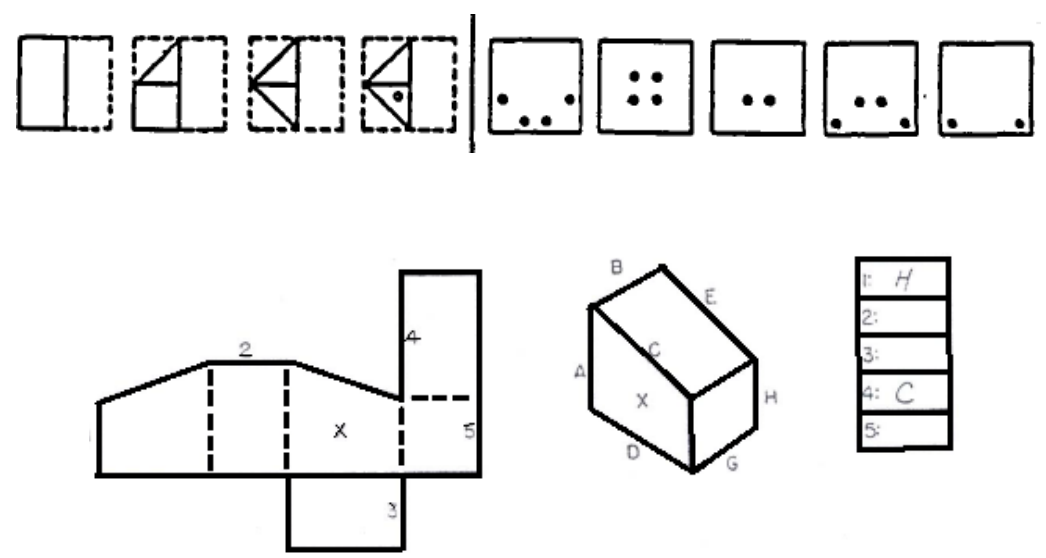
Winter vd. (1989) tarafindan geliştirilen MGMP Uzamsal Görselleştirme Testinde, verilen şekilde okla gösterilen küpün üzerine yeni bir küp eklenmesiyle oluşan yeni şeklin görüntüsü sorulmaktadır.

Alias, Black ve Gray (2002) tarafindan geliştirilen Küp Yapımı Testinde, her bir yüzeyinde farkIı resimler bulunan açık haldeki bir küpün kapalı halinin seçeneklerden arasından belirlenmesi sorulmaktadır.

Olkun (2003) tarafindan geliştirilen İki Boyutlu Geometride Uzamsal Görselleştirme Testinde, sol tarafta verilen şekilde boş bırakılan yerleri kaplamak için sağ taraftaki üçgenden kaç defa kullanılması gerektiği sorulmaktadır.

Yüksel ve Bülbül (2014) tarafindan geliştirilen Uzamsal Görselleştirme Testinde, açık hali üzerinde farklı şekiller bulunan bir küpün kapalı durumunda boş bırakılan herhangi bir yüzüne gelecek şeklin bulunması istenmektedir.
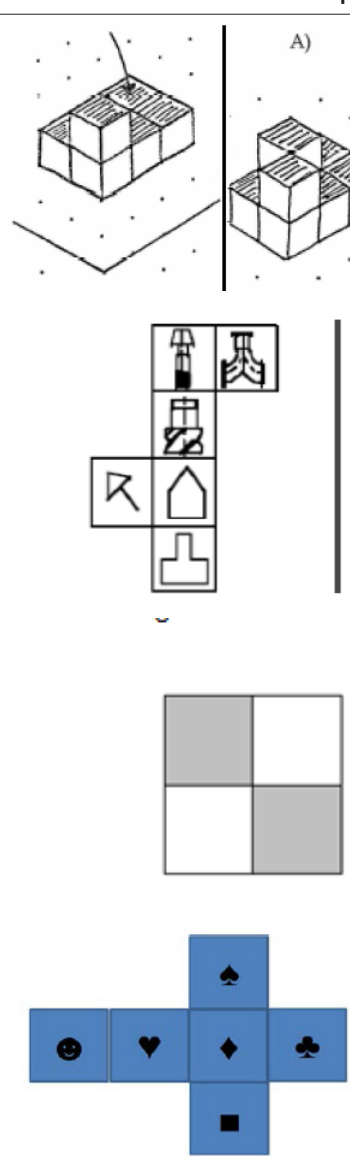

B)
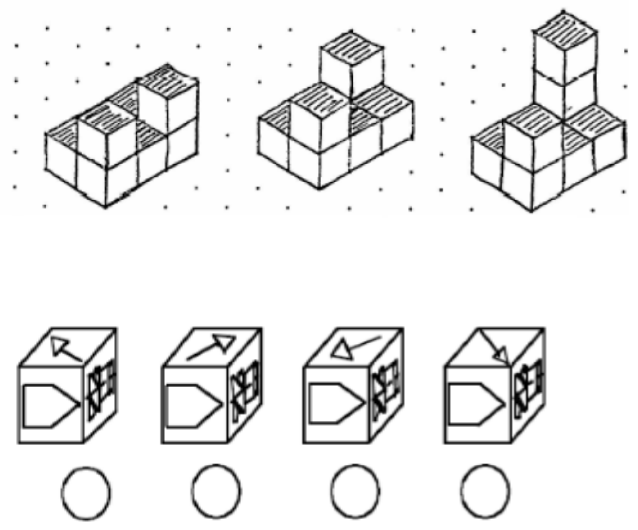

A) 2

B) 4

C) 6

D) 8

Uzamsal görselleştirme becerisi üzerine, farklı disiplinlerde yapılmış, farklı örneklemler (özellikle lise ve üniversite) üzerinde çalışılmış araştırmalar mevcuttur. Ancak yapılan araştırmalarda üzerinde çalışılan örneklemlerin farklı yaş gruplarında olmalarına rağmen belli başlı uzamsal görselleştirme testlerinin tekrar tekrar kullanıldığı dikkat çekmektedir. Ayrıca literatürde yer alan bu testlerde zihinde katlama, zihinde bütünleme, zihinde ayrıştırma, iki boyuttan üç boyuta dönüştürme gibi iki ya da üç boyutlu uzamsal görselleştirme becerileri farklı yaş grupları için geliştirilen, farklı uzamsal görselleştirme testlerinde yer almaktadır. Bu nedenle, bu araştırmanın amacı kâğıt katlama, zihinde ayrıştırma, zihinde bütünleme, iki boyuttan üç boyuta dönüştürme (küp yapımı) gibi iki ve üç boyutlu uzamsal görselleştirme becerilerini farklı soru tipleri ile aynı testte ölçen, yedinci sınıf seviyesine uygun çoktan seçmeli bir test geliştirmektir.

\section{Yöntem}

Bu araştırma, uzamsal görselleştirme becerilerini ölçmeye yönelik bir test geliştirme çalışmasıdır.

\section{Çalışma Grubu}

Testin pilot uygulaması, 2016-2017 eğitim-öğretim yılında Diyarbakır ili merkez ilçelerinde bulunun beş farklı ortaokulda öğrenim gören toplam 301 yedinci sınıf öğrencisiyle gerçekleştirilmiştir.

\section{Ölçme Aracı ve Geliştirilmesi}

Uzamsal Görselleştirme Testi (UGT), literatürde yer alan Minessota Şekil Panosu, WAIS Blok Tasarımı, FRT Kâğıt Katlama, MGMP Uzamsal Görselleştirme, Alias, Black ve Gray Küp Yapımı testlerinden yararlanılarak hazırlanmıştır. Testte yer alan sorular, her beceriye ait en az iki soru olacak şekilde SketchUp çizim programı ve NCTM ILLUMINATIONS İsometrik Drawing Tool (https://illuminations.nctm.org/activity.aspx?id=4182) kullanılarak hazırlanmıştır. İlk aşamada UGT dört seçenekli toplam 38 maddeden oluşmuştur. Hazırlanan test kapsam geçerliği için dokuz öğretim üyesinin ve iki ortaokul matematik öğretmeninin görüşlerine sunulmuştur. Öğretim üyelerinin sekizi matematik eğitimi alanında, biri ise ölçme ve değerlendirme alanında uzmandır. Matematik eğitimi alanındaki bir öğretim üyesinin, yüksek lisans ve doktora tezi uzamsal yetenek ile ilgili olup, bu alanda çok sayıda araştırması bulunmaktadır. Öğretim üyelerinden ve öğretmenlerden alınan dönütler doğrultusunda UGT'deki madde sayılarının fazla olduğu gerekçesiyle testten altı 
madde çıkarılmış ve kalan maddeler üzerinde gerekli düzeltmeler yapılmıştr. Ayrıca testteki maddeler üç öğrenciye uygulanmış ve anlaşılmayan yerlerde gerekli düzeltmeler yapılmıştr. Uzman görüşü alındıktan sonra geçerlik ve güvenirlik çalışmaları için öğrencilere uygulanacak olan 32 maddelik UGT'deki her bir beceriye ait soru sayısı Tablo 2'de verilmiştir.

\section{Tablo 2. UGT'deki her bir beceriye ait soru sayısı}

\begin{tabular}{lcccccccc}
\hline \multirow{2}{*}{$\begin{array}{l}\text { Uzamsal } \\
\text { Görselleştirme }\end{array}$} & \multicolumn{2}{c}{ İki Boyutlu Uzamsal Görselleştirme } & \multicolumn{4}{c}{ Üç Boyutlu Uzamsal Görselleştirme } \\
\cline { 2 - 8 } Testi & $\begin{array}{c}\text { Zihinde } \\
\text { Bütünleme }\end{array}$ & $\begin{array}{c}\text { Zihinde } \\
\text { Ayrıştırma }\end{array}$ & $\begin{array}{c}\text { Kâğıt } \\
\text { Katlama }\end{array}$ & $\begin{array}{c}\text { Zihinde } \\
\text { Bütünleme }\end{array}$ & $\begin{array}{c}\text { Zihinde } \\
\text { Ayrıştırma }\end{array}$ & $\begin{array}{c}\text { Tüp } \\
\text { Temas }\end{array}$ & $\begin{array}{c}\text { Küp } \\
\text { Sayma }\end{array}$ & $\begin{array}{c}\text { Küp } \\
\text { Açınımı }\end{array}$ \\
Soru Sayısı & 6 & 6 & 4 & 4 & 4 & 2 & 2 & 4 \\
\hline Toplam & 16 & & & & 16 & \\
\hline
\end{tabular}

Tablo 3'te UGT'de yer alan iki boyutlu uzamsal görselleştirme sorularından zihinde bütünleme, zihinde ayrıştrrma ve kâğıt katlama sorularına ait birer örnek verilmiştir.

Tablo 3. UGT'de yer alan iki boyutlu uzamsal görselleştirme soru örnekleri

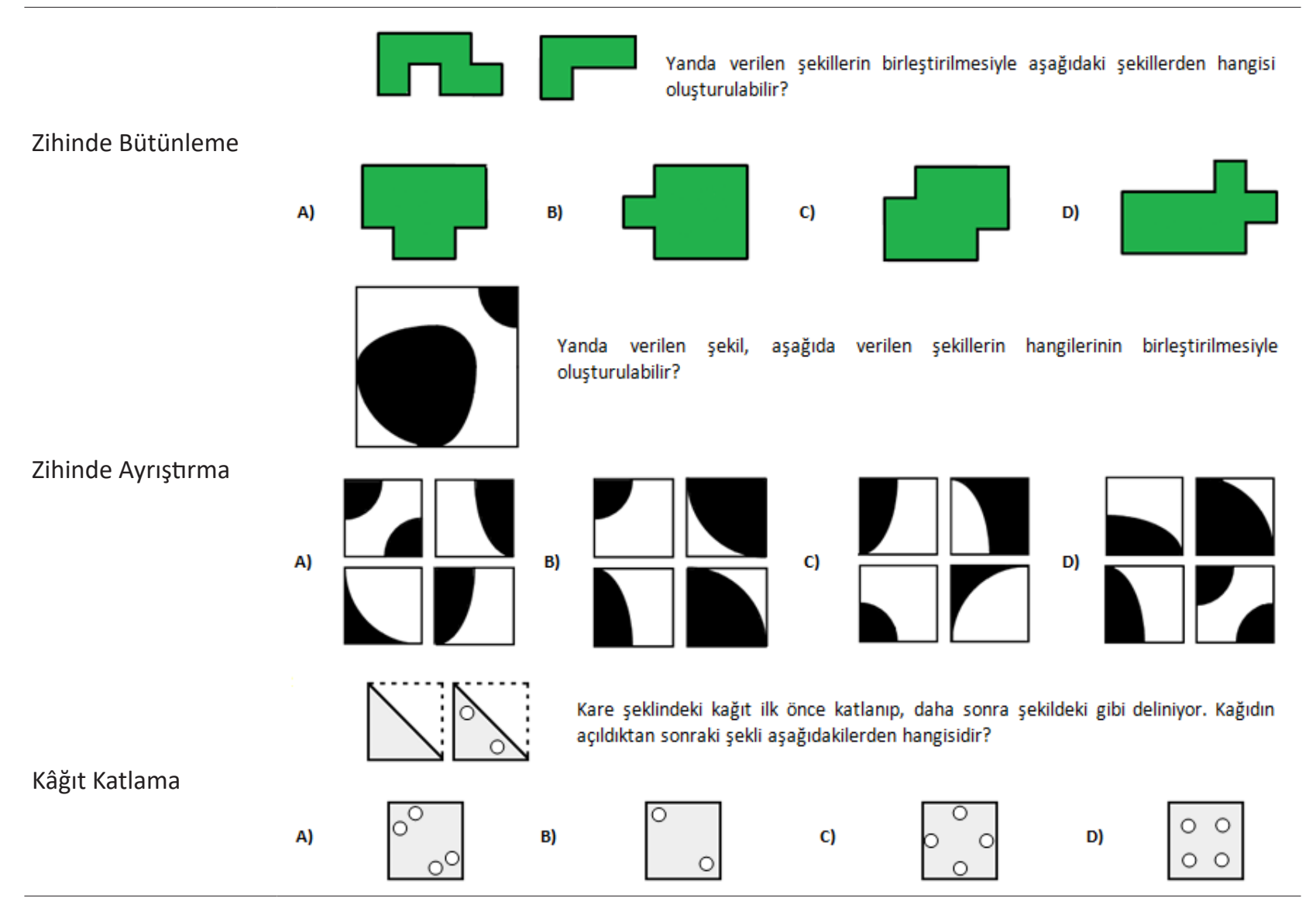

Tablo 4'te UGT'de yer alan üç boyutlu uzamsal görselleştirme sorularından zihinde bütünleme, zihinde ayrıştırma, küp temas sayısı, küp sayma ve küp açınımı sorularına ait birer örnek verilmiştir. 
Tablo 4. UGT'de yer alan üç boyutlu uzamsal görselleştirme soru örnekleri

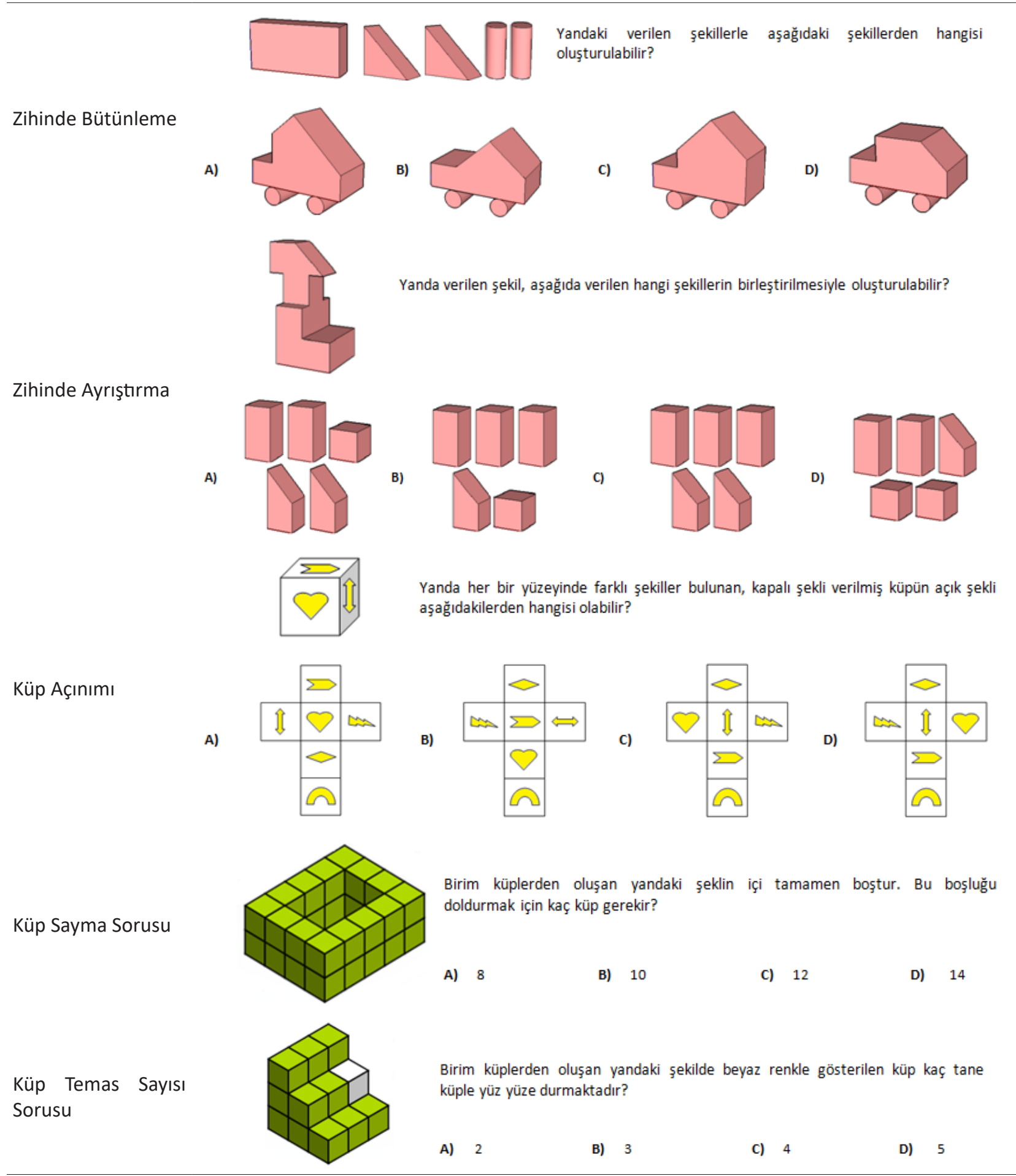

\section{Verilerin Analizi}

Öğrencilerin teste verdikleri yanıtlar öncelikle "Microsoft Office Excel" programına A, B, C, D olarak işlenmiştir. Daha sonra bu veriler, doğru yanıtlanmış maddeler için " 1 ", yanlış yanıtlanmış ve boş bırakılmış maddeler için " 0 " olacak şekilde yapay olarak iki kategorili kesikli hale dönüştürülmüştür.

Testten elde edilen puanların normal dağılıp dağılmadığı "SPSS 21" programı ile analiz edilmiştir. Dağılımın normalliğinin incelenmesinde; histogram, normal $Q-Q$, detrended normal Q-Q ve kutu-çizgi grafiği gibi grafikler ile inceleme; basıklık ve çarpıklık değerleri gibi istatistiklerin kullanılması; Shapiro-Wilk ve Kolmogorov Smirnov hipotez testlerin kullanılması şeklinde üç yöntem vardır. Özellikle 100 ve daha geniş örneklemlerde grafik yöntemi örneklemden görece bağımsız olduğu için grafik ile inceleme daha sık kullanılmaktadır. Hipotez testlerin kullanımında ise örneklem büyük- 
lüğü arttkça küçük farkların anlamlı çıkma olasılı̆̆ının artma eğilimi vardır. Bu nedenle, UGT’nin geçerlik ve güvenirlik çalışmaları için test 301 öğrenciye uygulandı̆̆ından, testten elde edilen puanların normalliğinin incelenmesinde grafikler ile basıklık ve çarpıklık değerleri dikkate alınmıştır (Büyüköztürk, 2011; Çokluk, Şekercioğlu ve Büyüköztürk, 2012).

Testin faktör yapılarını belirlemek için "FACTOR 10.3.01" ve "SPSS 21" programlarından yararlanılarak tetrakorik korelasyon matrisi üzerinden açımlayııı faktör analizi (AFA) yapılmıştır. Tetrakorik korelasyon katsayısı iki kategorili yapay süreksiz iki değişken arasındaki ilişkinin derecesini belirlemek için kullanılmaktadır (Baykul ve Güzeller, 2014; Kan, 2011). Bu çalışmada tetrakorik korelasyon matrisi üzerinden AFA yapılmasının nedeni ise öğrencilerin testteki maddelere verdikleri yanıtlar 1-0 şeklinde yapay olarak iki kategorili hale dönüştürüldüğü içindir.

AFA sonucunda elde edilen faktör yapılarının, bir model olarak doğrulanıp doğrulanmadığını belirlemek amacıyla "LISREL 8.54" programından yararlanılarak doğrulayıcı faktör analizi (DFA) uygulanmıştr. LISREL'de aksi belirtilmediği takdirde, yapılan analizlerde En Yüksek Olabilirlik Kestirim (Maximum Likelihood) Yöntemi ve korelasyon ya da kovaryans matrisleri kullanılmaktadır. Eğer data 1-0 şeklinde kategorik ise Asimptotik Kovaryans Matrisi (Asymptotic Covariance Matrix) ile Ağılıklı En Küçük Kareler (Weighted Least Squares) Yöntemi'nin kullanılması önerilmektedir (Kline, 2011; Şimşek, 2007). Bu çalışmada Asimptotik Kovaryans Matrisi ile Ağırlıklı En Küçük Kareler Yönteminden yararlanılarak DFA yapılmasının sebebi, testten elde edilen verilerin 1-0 şeklinde iki kategorili hale dönüştürüldüğü içindir.

AFA ve DFA sonrasında madde güçlüğü ve ayırt edicilik işlerliği ile ilgili bulguları ortaya koymak için $A, B, C, D$ olarak işlenen veriler üzerinden "ITEMAN 3" programı ile madde analizi yapılmıştır. Madde ile ölçülmek istenen özellik doğası itibariyle gerçekte sürekli bir değişken iken yapay olarak iki kategorili kesikli hale getirilen madde puanları ile sürekli değişken olma özelliğine sahip test puanları arasındaki ilişki çift serili korelasyon katsayısı (biserial) ile belirlenebilir (Büyüköztürk, Çokluk ve Köklü, 2011; Kan, 2011). Bu nedenle ayırt etme gücü olarak, çift serili korelasyon katsayısı (biserial) dikkate alınmıştır.

KR-20, bir test maddesine verilen cevaplar 0 ve 1 ile puanlandığında testlerin güvenirliğini belirlemek için kullanılan iç tutarlılık güvenirlik katsayısıdır (Büyüköztürk, Kılıç Çakmak, Akgün, Karadeniz ve Demirel, 2016). Bu nedenle, UGT'nin güvenirliğini belirlemek için "ITEMAN 3" programı ile KR-20 (alpha) iç tutarlılık güvenirlik katsayı hesaplanmıştır.

\section{Bulgular}

UGT'nin geliştirilmesi aşamasında, kapsam geçerliliği için uzman görüşleri alındıktan sonra sırasıyla AFA, DFA, madde analizi ve güvenirlik çalışmalarına yer verilmiştir.

\section{Açımlayıcı Faktör Analizi}

UGT'nin, faktör yapılarını belirlemek amacıyla ilk olarak açımlayıcı faktör analizi (AFA) yapılmıştır. Bunun için öncelikle örneklem büyüklüğü incelenmiştir. Kline’a (1994) göre, araştırma kapsamındaki 301 kişilik örneklem büyüklüğünün faktör analizi için yeterli olduğu söylenebilir (Akt:Çokluk vd., 2012). Ayrıca veri setinin faktör analizi için uygun olup olmadığını belirlemek için Kaiser-Meyer-Olkin (KMO) katsayısı ve Bartlett Küresellik Testi de incelenmiştir. KMO değerinin .79 ve Bartlett Küresellik Testi sonucunda elde edilen ki-kare değerinin anlamlı olduğu görülmüştür, $\left[\chi^{2}(496)=1602.8\right.$, $p=.000]$. KMO değerinin $.70^{\prime}$ in üzerinde olması, örneklem büyüklüğünün faktör analizi yapabilmek için yeterli olduğu; ki-kare değerinin anlamlı çıkması ise verilerin çok değişkenli normal dağıımdan geldiği anlamına gelmektedir (Seçer, 2013). Aynı zamanda, basıklık (.178) ve çarpıklık (-.208) değerlerinin $+1,-1$ aralığında olması ve histogram, normal $Q-Q$, detrended normal $Q-Q$, kutu-çizgi grafiklerinin normal dağılım özelliği göstermelerinden dolayı, dağılımın normale yakın olduğuna karar verilmiştir (Büyüköztürk, 2011; Çokluk vd., 2012).

Tetrakorik korelasyon matrisi üzerinden yapılan AFA sonucunda, öz değeri 1'in üzerinde 10 faktör olduğu gözlenmiştir. Ancak AFA da önemli faktör sayısına karar vermede öz değer ile birlikte, açıklanan varyans oranı ve faktörlerin öz değerlerine dayalı olarak çizilen çizgi grafiğinin dikkate alınması önerilir (Büyüköztürk, 2011). Temel bileşenler analizi yöntemi ile herhangi bir döndürme yapılmadan elde edilen analiz sonuçları incelendiğinde, birinci faktör toplam varyansa \%19.34 (öz değer=6.19) ve ikinci faktör \%14.70 (öz değer=4.70) oranında bir katkı sağlamaktadır. Üçüncü ve diğer faktörlerin toplam varyansa katkıları sırasıyla \%5.46 (öz değer=1.75), \%4.46 (öz değer=1.43), \%4.31 (öz değer=1.38), \%3.91 (öz değer=1.25), \%3.70 (öz değer=1.18), \% 3.51 (öz değer=1.12), \%3.31 (öz değer=1.06) ve \% 3.15 (öz değer=1.01) dir. Illk iki bileşenin varyansa önemli ölçüde katkı sağladığı, üçüncü bileşenden itibaren bu katkının azaldığı ve birbirlerine yakın olduğu görülmektedir. Buna göre, faktör sayısının iki olarak belirlenmesine karar verilebilir ancak faktörlerin öz değerlerine dayalı olarak çizilen çizgi grafiğinin de dikkate alınması gerekir. Şekil 1'de çizgi grafiği verilmiştir. 


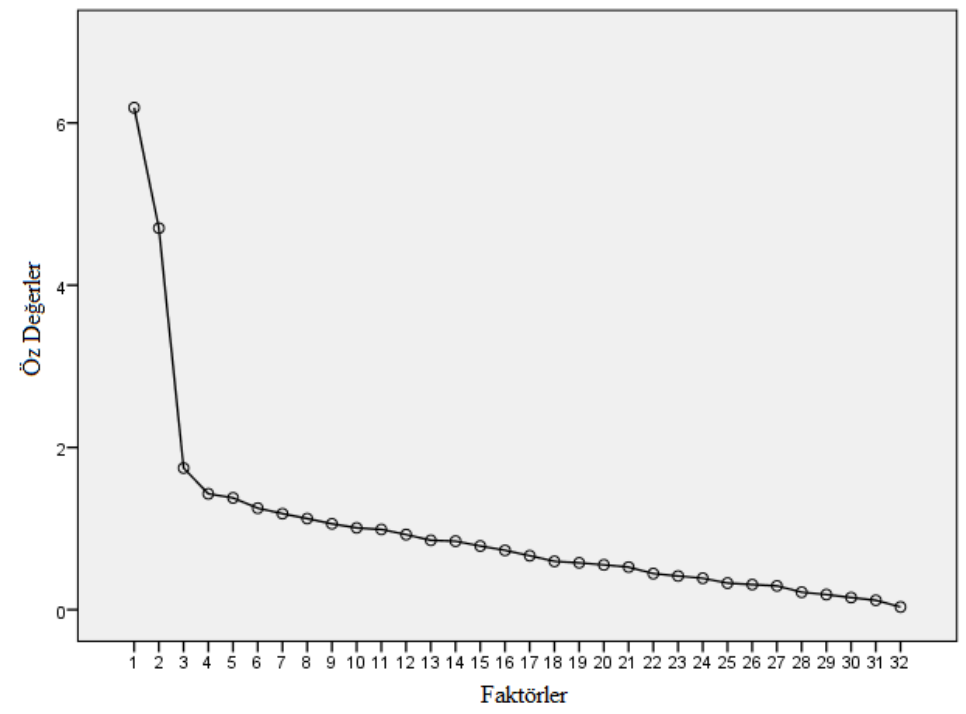

\section{Şekil 1. UGT’nin faktör öz değerlerine ait çizgi grafiği}

Şekil 1 incelendiğinde, üçüncü noktadan sonra eğimin azaldığı ve üçüncü noktadan sonraki bileşenlerin varyansa yaptıkları katkıların hem küçük hem de birbirlerine yakın olduğu görülmektedir. Dahası, testin geliştirilmesi sürecinde belirlenen teorik yapıda beklenen faktör yapısı ile uyumlu olması açısından da faktör sayısının iki olmasına karar verilmiştir.

İki faktör ile sınırlandırılıp temel bileşenler analizi ve varimax döndürme işlemi ile maddeler iki ayrı faktörde toplanmıştır. İlk 16 madde birinci faktörde, son 16 madde ikinci faktörde toplanmıştr. Belirlenen faktörler, birinci faktör için "iki Boyutlu Uzamsal Görselleştirme" ve ikinci faktör için "Üç Boyutlu Uzamsal Görselleştirme" olarak isimlendirilmiştir. Maddeler binişiklik ve faktör yük değerlerinin kabul düzeyini karşılayıp karşılamaması açısından değerlendirildiğinde, 6 . maddenin faktör yük değerinin her iki faktör için .30'dan düşük olduğu görülmüştür. Faktör analizinde faktör yükünün en az .30 olması önerilmektedir (Büyüköztürk, 2011; Çokluk vd., 2012; Seçer, 2013). Bu nedenle, 6. madde .30 kabul düzeyinin altında olduğu için testten çıkarılmasına karar verilmiştir. UGT'nin son durumdaki faktör yükleri ve açıkladıkları varyans oranlarına ilişkin bilgiler Tablo 5'te gösterilmiştir.

\section{Tablo 5. UGT'nin faktör yükleri ve açıkladıkları varyans oranları}

\begin{tabular}{|c|c|c|c|}
\hline Madde Numarası & $\begin{array}{c}\text { İki Boyutlu Uzamsal Görselleştirme } \\
\text { Faktör Yükleri }\end{array}$ & Madde Numarası & $\begin{array}{c}\text { Üç Boyutlu Uzamsal Görselleştirme } \\
\text { Faktör Yükleri }\end{array}$ \\
\hline 1. & .61 & 17. & .65 \\
\hline 2. & .52 & 18. & .68 \\
\hline 3. & .63 & 19. & .51 \\
\hline 4. & .59 & 20. & .45 \\
\hline 5. & .43 & 21. & .60 \\
\hline 7. & .48 & 22. & .65 \\
\hline 8. & .48 & 23. & .57 \\
\hline 9. & .60 & 24. & .59 \\
\hline 10. & .69 & 25. & .54 \\
\hline 11. & .60 & 26. & .57 \\
\hline 12. & .63 & 27. & .64 \\
\hline 13. & .58 & 28. & .60 \\
\hline 14. & .72 & 29. & .66 \\
\hline 15. & .64 & 30. & .67 \\
\hline \multirow[t]{2}{*}{16.} & .60 & 31. & .44 \\
\hline & & 32. & .57 \\
\hline Açıklanan Varyans & $\% 20.80$ & Açıklanan Varyans & $\% 15.42$ \\
\hline
\end{tabular}

Toplam Varyans: \%36.22 
Tablo 5'te, 6. madde testten çıkarıldıktan sonra geriye kalan maddelerin faktör yük değerlerinin birinci faktör için .43 ile .72, ikinci faktör için .44 ile .68 arasında değiştiği gözlenmiştir. Ayrıca, açıklanan varyans oranlarının, birinci faktör için \%20.80, ikinci faktör için \%15.42 ve her iki faktör için toplam varyansın ise \%36.22 olduğu gözlenmektedir.

\section{Doğrulayıcı Faktör Analizi}

AFA sonucunda, UGT’nin iki faktörlü yapısının, bir model olarak doğrulanıp doğrulanmadığı birinci düzey doğrulayıcı faktör analizi (DFA) ile test edilmiştir. Yapılan DFA sonucunda ilk kontrol edilmesi gereken, $t$ değerlerinin anlamlılık düzeyidir (Çokluk vd., 2012). Analize dâhil edilen 31 madde için t değerlerinin 7.82 ile 20.56 arasında olduğu tespit edilmiştir. Kline’a (2011) göre tüm t değerleri 2.58'den büyük olduğu için bu değerlerin .01 düzeyinde anlamlı olduğu söylenebilir. Daha sonra incelenen standardize edilmiş katsayıların (faktör yükleri), birinci faktör için .36 ile .65 ve ikinci faktör için .42 ile .72; hata varyanslarının ise birinci faktör için .57 ile .87 ve ikinci faktör için .48 ile .82 arasında değiştiği belirlenmiştir. Seçer'e (2015) göre DFA'da her bir faktörün yük değerinin en az .30 olmasına ve Kline’a (2011) göre hata varyanslarının .90'dan küçük olmasına dikkat edilmelidir. Buna göre, standardize edilmiş katsayılar ve hata varyansları ile ilgili herhangi bir problem olmadığı söylenebilir.

DFA'da sınanan modelin yeterliliğini ortaya koymak amacıyla $\chi^{2} / \mathrm{sd}, \mathrm{RMSEA}, \mathrm{GFI}, \mathrm{AGFI}, \mathrm{SRMR}, \mathrm{NNFI}$ ve CFI uyum indeksleri incelenmiştir. Bununla birlikte genel olarak, $\chi^{2} / \mathrm{sd}$ oranının 3'ün altında olması mükemmel uyuma, 5'in altında olması orta düzey uyuma karşılık gelmektedir (Çokluk vd., 2012). RMSEA'nın .05'ten küçük olması mükemmel, .08'den küçük olması kabul edilebilir uyuma; GFI ile AGFI indekslerinin .90'ın üzerinde olması mükemmel uyuma, .85'in üzerinde olması kabul edilebilir uyuma; NNFI ile CFI indekslerinin .95'in üzerinde olması mükemmel uyuma, .90'ın üzerinde olması kabul edilebilir uyuma karşılık gelmektedir (Marcholudis ve Schumacher, 2007; Akt: Seçer, 2015). SRMR'nin ise .05'ten küçük olması mükemmel uyum ve .10'dan küçük olması kabul edilebilir uyum ölçütü olarak alınmaktadır (Bayram, 2013; Hu ve Bentler, 1999; Kline, 2011). Buna göre; UGT modelinin yeterliğini ortaya koymak amacıyla incelenen uyum indeks değerleri ve uyum indekslerine ilişkin kabul edilebilir ve mükemmel uyum değerleri doğrultusunda ortaya çıkan sonuçlar Tablo 6'da gösterilmiştir.

Tablo 6. UGT’nin uyum indeks değerleri ve sonuçlar

\begin{tabular}{ccc}
\hline Uyum Indeksleri & Uyum İndeks Değerleri & Sonuç \\
\hline$\chi^{2}$ & $641.98(p=.00 \mathrm{sd}=433)$ & \\
$\chi^{2} / \mathrm{sd}$ & 1.48 & Mükemmel Uyum \\
$\mathrm{RMSEA}$ & .040 & Mükemmel Uyum \\
$\mathrm{GFI}$ & .94 & Mükemmel Uyum \\
$\mathrm{AGFI}$ & .93 & Mükemmel Uyum \\
$\mathrm{SRMR}$ & .090 & Kabul Edilebilir Uyum \\
$\mathrm{NNFI}$ & .77 & Zayıf Uyum \\
$\mathrm{CFI}$ & .79 & Zayıf Uyum \\
\hline
\end{tabular}

Tablo 6 incelendiğinde, $\chi^{2} /$ sd, RMSEA, GFI ve AGFI indekslerinin mükemmel; SRMR indeksinin kabul edilebilir; NNFI ve CFI indekslerinin ise zayıf uyum gösterdiği görülmektedir. Kline’a (2011) göre, DFA sonucunda elde edilen zayıf uyum gösteren indekslerin olması durumunda, çıkt dosyalarında yer alan modifikasyon önerilerinin dikkate alınması gerekebilir. Bu nedenle, analiz sonundaki aynı boyut içinde yer alan maddeler arasındaki modifikasyon önerileri incelenmiştir. UGT'de her bir beceriyi ölçen en az iki madde bulunduğundan dolayı kuramsal açıdan birbirine yakın birden fazla madde ile bağlanması önerilen maddeler (11 ve 20) testten çıkarılmış ve modifikasyonun yine kuramsal açıdan birbirine yakın olan maddeler (15 ile 16, 24 ile 25 ve 30 ile 32) arasında yapılmasına karar verilmiştir.

11. ve 20. maddeler testten çıkarıldıktan ve yapılan modifikasyonlardan sonra kalan 29 madde için yeni t değerlerinin 7.39 ile 18.24 arasında ve .01 düzeyinde anlamlı olduğu gözlenmiştir. Şekil 2'de, yeni standardize edilmiş katsayılar (faktör yükleri) birinci faktör için .36 ile .68 ve ikinci faktör için .39 ile .63; yeni hata varyansları ise birinci faktör için .53 ile .87 ve ikinci faktör için .60 ile .85 arasında değiştiği görülmektedir. Yeni uyum indeksleri ve uyum indekslerine ilişkin kabul edilebilir ve mükemmel uyum değerleri doğrultusunda ortaya çıkan sonuçlar Tablo 7'de gösterilmiştir. 
Tablo 7. UGT’nin uyum indeks değerleri ve sonuçlar

\begin{tabular}{ccc}
\hline Uyum İndeksleri & Uyum İndeks Değerleri & Sonuç \\
\hline$\chi^{2}$ & $473.53(\mathrm{p}=.00 \mathrm{sd}=376)$ & \\
$\chi^{2} / \mathrm{sd}$ & 1.26 & Mükemmel Uyum \\
$\mathrm{RMSEA}$ & .029 & Mükemmel Uyum \\
$\mathrm{GFI}$ & .96 & Mükemmel Uyum \\
$\mathrm{AGFI}$ & .95 & Mükemmel Uyum \\
SRMR & .074 & Kabul Edilebilir Uyum \\
$\mathrm{NNFI}$ & .92 & Kabul Edilebilir Uyum \\
$\mathrm{CFI}$ & .93 & Kabul Edilebilir Uyum \\
\hline
\end{tabular}

Tablo 7'ye göre, $\chi^{2}$ / sd, RMSEA, GFI ve AGFI indeksleri mükemmel uyum; SRMR, NNFI ve CFI indeksleri kabul edilebilir uyum göstermektedir. Buna göre, bu sonuç 29 maddelik UGT'nin iki faktörlü yapısının birinci düzey DFA sonucunda, bir model olarak doğrulandığını göstermektedir. UGT'nin birinci düzey DFA'dan elde edilen iki faktörlü modeline ilişkin path diagramı Şekil 2'de görülmektedir.

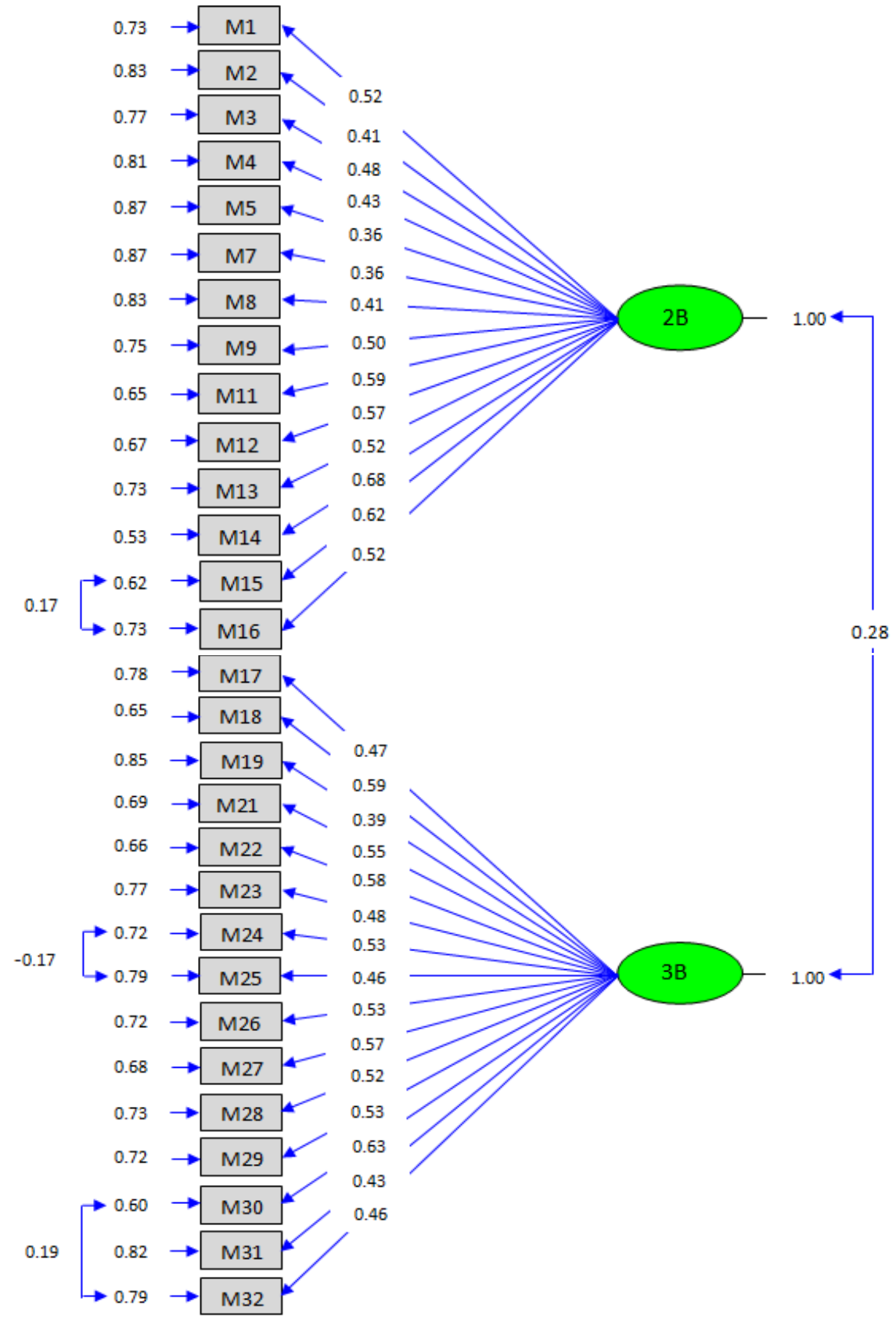

Şekil 2. UGT'nin birinci düzey DFA'dan elde edilen iki faktörlü modeline ilişkin path diagramı 
İkinci düzey DFA modellerinde, ikinci düzeyi tanımlayabilmek için en az üç birinci düzey faktör olmalıdır. Aksi takdirde, ikinci düzeyden birinci düzeye olan doğrudan etki yetersiz bir biçimde tanımlanmış olabilir. Ayrıca her birinci düzey faktör, en az iki göstergeye sahip olmalıdır (Kline, 2011). UGT'nin birinci düzey faktör sayısının iki ve birinci düzey faktörlerin ise ikiden fazla göstergesi olduğu görülmektedir. Birinci düzey faktör sayısı üçten az olduğundan dolayı, ikinci düzey DFA gerekliliklerinden biri karşılanmamış ve ikinci düzey DFA yapılamamıştr.

\section{Madde Analizi}

UGT'de yer alan 29 maddenin işlerliğini belirlemek amacıyla madde analizi yapılmıştır. Tablo 8'de UGT'nin madde analizi sonuçlarına yer verilmiştir.

Tablo 8. UGT’nin madde analizi sonuçları

\begin{tabular}{ccccccc}
\hline Madde & \multicolumn{2}{c}{ iki Boyutlu Uzamsal Görselleştirme } & Madde & \multicolumn{2}{c}{ Üç Boyutlu Uzamsal Görselleştirme } \\
\cline { 2 - 3 } Numarası & Ayırt Edicilik & Güçük & Numarası & Ayırt Edicilik & Güçük \\
\hline 1. & .65 & .52 & 17. & .68 & .81 \\
2. & .57 & .33 & 18. & .73 & .76 \\
3. & .67 & .65 & 19. & .56 & .57 \\
4. & .61 & .28 & 21. & .67 & .31 \\
5. & .51 & .49 & 22. & .69 & .32 \\
7. & .55 & .50 & 23. & .61 & .53 \\
8. & .56 & .48 & 24. & .61 & .51 \\
9. & .65 & .69 & 25. & .57 & .48 \\
10. & .72 & .50 & 26. & .63 & .65 \\
12. & .65 & .41 & 27. & .70 & .56 \\
13. & .63 & .47 & 28. & .66 & .65 \\
14. & .75 & .69 & 29. & .69 & .68 \\
15. & .70 & .55 & 30. & .71 & .40 \\
16. & .66 & .58 & 31. & .51 & .42 \\
& & & 32. & .60 & .49 \\
\hline Toplam & .63 & .51 & Toplam & .64 & .54 \\
\hline
\end{tabular}

Tablo 8'de görüldüğü üzere, UGT'de yer alan maddelerin ayırt edicilik düzeylerinin (çift serili korelasyon katsayısı-biserial), birinci faktör için .51 ile .75 , ikinci faktör için .51 ile .73 arasında değiştiği; testin ortalama ayırt edicilik düzeyinin ise birinci faktör için .63 ve ikinci faktör için .64 olduğu tespit edilmiştir. Testte yer alan maddelerin güçlük düzeylerinin birinci faktör için .28 ile .69, ikinci faktör için .31 ile .81 arasında değişţği; testin ortalama güçlük düzeyinin ise birinci faktör için .51 ve ikinci faktör için .54 olduğu tespit edilmiştir. Tekin’e (2010) göre ayırt edicilik düzeyleri .40 ve üzerinde olan maddelerin ayırt etme gücü yüksektir. Ayrıca, testte yer alan maddeler farklı güçlük düzeylerine sahip olmalı ve testin ortalama güçlüğü ise .50 civarında olmalıdır. Bununla birlikte, Kan’a (2011) göre testte yer alan maddelerin güçlük indekslerinin ortalaması .50 olacak şekilde, indeksler .10 ile .90 arasında dağılım göstermelidir. Buna göre UGT, farklı güçlük düzeylerine ve yüksek ayırt ediciliğe sahip maddelerden oluşan, orta güçlükte ve ayırt ediciliği yüksek bir test olduğu söylenebilir.

\section{Güvenirlik}

UGT'de yer alan 29 maddenin güvenirliği ile ilgili sonuçlara Tablo 9'da yer verilmiştir.

\section{Tablo 9. UGT’nin güvenirlik sonuçları}

\begin{tabular}{lc}
\hline & KR-20 iç tutarlılık katsayısı \\
\hline İki Boyutlu Uzamsal Görselleştirme & .77 \\
Üç Boyutlu Uzamsal Görselleştirme & .78 \\
Testin Geneli & .78 \\
\hline
\end{tabular}

Tablo 9'da görüldüğü üzere UGT'nin 14 maddeden oluşan birinci faktör için KR-20 iç tutarlılık katsayısı .77 ve 15 maddeden oluşan ikinci faktör için .78 olarak hesaplanmıştır. Testin geneline ait KR-20 iç tutarlılık katsayısı .78 olarak hesaplanmıştr. Genel olarak, güvenirlik katsayısı .70 ve daha büyük olan testler güvenilir olarak kabul edilmektedir (Büyüköztürk, 2011, Urbina, 2004). Bu durumda, UGT’nin güvenilir bir test olduğu söylenebilir. 


\section{Sonuç ve Öneriler}

Uzamsal görselleştirme, iki ve üç boyutlu nesnelerin zihinde canlandırılan hareketlerini anlayabilme ve bu hareketleri gerçekleştirebilme becerisidir (Clements, 1998). Bu beceriyi ölçen standart testlerde zihinde katlama, zihinde bütünleme ve iki boyuttan üç boyuta dönüştürme gibi zihinsel eylemler ile ilgili maddeler yer almaktadır (Pellegrino vd., 1984). İki boyuttan üç boyuta dönüştürme ile ilgili zihinsel eylemler Purdue Uzamsal Görselleştirme Testi (Görselleştirmeler), Ayrımsal Yetenek Testi (Uzay Illişkileri Alt Testi), Yüzey Geliştirme Testi gibi testlerle ölçülmektedir. Zihinde katlama ile ilgili zihinsel eylemler Kâğıt Katlama Testi ile ölçülmektedir. Zihinde bütünleme ve ayrıştrma ile ilgili zihinsel eylemler ise Minessota Şekil Panosu Testi, MGMP Uzamsal Görselleştirme Testi, íki Boyutlu Geometride Uzamsal Görselleştirme Testi gibi testlerle ölçülmektedir. Görüldüğü üzere iki boyuttan üç boyuta dönüştürme, zihinde katlama, zihinde bütünleme ve ayrıştırma gibi zihinsel eylemlere genellikle lise ve üniversite öğrencilerinin seviyelerine uygun, farklı uzamsal görselleştirme testlerinde yer verilmiştir. Piaget'e göre soyut düşünmenin başladığı ve hızla geliştiği dönem ilköğretim ikinci kademedir (Senemoğlu, 2012). Beşinci ve altıncı sınıf öğrencileri yaşları itibariyle somut düşünmeden soyut düşünmeye geçiş döneminin başındadırlar. Bu nedenle bu araştırmada soyut düşünme becerisi gerektiren uzamsal görselleştirme becerisinin ölçülebilmesi için soyut işlemler dönemde olan yedinci sınıf öğrencileri ile çalışılmıştır. Zihinde bütünleme ve ayrıştırma gibi zihinsel eylemleri içeren İki Boyutlu Geometride Uzamsal Görselleştirme Testi dördüncü ve beşinci sınıf, MGMP Uzamsal Görselleştirme Testi de ortaokul öğrencilerinin uzamsal görselleştirme becerilerini ölçmek amacıyla geliştirilmiştir. MGMP Uzamsal Görselleştirme Testi, ortaokul öğrencilerinin uzamsal görselleştirme becerilerini ölçmek amacıyla geliştirilmiş olmasına rağmen Robichaux (2000)'un belirttiği gibi soruların çoğundaki şekiller karmaşık olduğundan dolayı birçok çalışmada (Akbay, 2015; Dursun, 2010; Erkek, Işıksal ve Çakıroğlu, 2017) lise ve üniversite öğrencileri üzerinde uygulanmıştır. Ayrıca bu test zihinde katlama, iki boyutlu zihinde bütünleme, iki boyutlu zihinde ayrıştırma, iki boyutta boyuttan üç boyuta dönüştürme (küp yapımı) ile ilgili zihinsel eylemleri içermeyip, sadece üç boyutlu uzamsal görselleştirme becerileri ölçmektedir. Bu nedenle, bu araştrmada kâğıt katlama, zihinde ayrıştırma, zihinde bütünleme, küp yapımı, küp sayma, küp temas sayısı gibi çok sayıda iki ve üç boyutlu uzamsal görselleştirme becerilerini farklı soru tipleri ile aynı testte ölçen, yedinci sınıf seviyesine uygun, kapsamlı çoktan seçmeli bir test geliştirmek amaçlanmıştir. Bu amaç doğrultusunda geliştirilen uzamsal görselleştirme testi yedinci sınıf öğrencileri ile gerçekleştirilen geçerlik ve güvenirlik çalışmasıyla ortaya konmuştur. Kapsam geçerliği için uzman görüşü aldıktan sonra öncelikle testin faktör yapılarını belirlemek amacıyla Tetrakorik Korelasyon Matrisi üzerinden açımlayııı faktör analizi yapılmış ve 6. madde testten çıkarılarak "iki boyutlu uzamsal görselleştirme" ve "üç boyutlu uzamsal görselleştirme" şeklinde iki faktörlü bir yapı elde edilmiştir. Daha sonra testin iki faktörlü yapısının bir model olarak doğrulanıp doğrulanmadığını belirlemek için Asimptotik Kovaryans Matrisi ile Ağırlıkıı En Küçük Kareler Yöntemi'nden yararlanılarak doğrulayıcı faktör analizi uygulanmıştır. 11. ve 20. maddeler testten çıkarılıp, birbiri ile kuramsal açıdan yakın olan 15 . ve 16., 24. ve 25., 30. ve 32. maddeler arasında modifikasyon yapıldıktan sonra iki faktörlü yapının yeterli uyum indekslerine sahip olduğu görülmüştür. 29 madde için madde analizi yapılmış; testin farklı güçlük düzeylerine ve yüksek ayırt ediciliğe sahip maddelerden oluşan, orta güçlükte ve ayırt ediciliği yüksek bir test olduğu ortaya çıkmıştır. 14 maddeden oluşan birinci faktör için KR-20 iç tutarlılık katsayısı .77 ve 15 maddeden oluşan ikinci faktör için .78 olarak hesaplanmıştır. Testin geneline ait KR-20 iç tutarlılık katsayısı .78 olarak hesaplanmışttr. Literatürde uzamsal görselleştirme becerilerini ölçmeye yönelik geliştirilen testlerin genellikle güvenirlikleri ile bilgilerine yer verilmiş ve güvenilir testler oldukları vurgulanmıştır. Örneğin Ekstrom, French, Harmon ve Derman (1976) tarafindan geliştirilen ve Delialioğlu (1996) tarafindan Türkçe'ye çevrilen Kağıt Katlama ve Yüzey Geliştirme Testlerinin güvenirlik katsayıları sırasıyla .84 ve .82; Guay (1976) tarafindan geliştirilen Purdue Uzamsal Görselleştirme Testinin .80; Alias, Black ve Gray (2002) tarafindan geliştirilen Uzamsal Görselleștirme Testinin .55; Oklun (2003) tarafindan geliștirilen İki Boyutlu Geometride Uzamsal Görselleştirme Testinin ise .77'dir. Ayrıca Turğut (2007) tarafindan Türkçe'ye çevrilen MGMP Uzamsal Görselleştirme Testinin güvenirliğinin .81 olduğu belirtilmiştir. Diğer testlerden farklı olarak Yüksel ve Bülbül (2014) tarafindan üniversite öğrencileri için geliştirilen uzamsal görselleştirme testinde madde analizi, geçerlik-güvenirlik analizi yapılmış, tek faktörlü yeterli uyum indekslerine sahip olduğu görülmüştür. Güvenirlik katsayısı .84 olarak hesaplanmıştır. Bu testte ise kapsam geçerliği için uzman görüşü aldıktan sonra testin açımlayıc faktör analizi, doğrulayıcı faktör analizi, madde analizi ve güvenirlik çalışmalarına yer verilerek uzamsal görselleştirme testinin geçerli ve güvenilir bir test olduğu ortaya konmuştur. Bu araştırmada geliştirilen uzamsal görselleştirme testinden yola çıkılarak araştrmacılara, uzamsal yeteneğin farklı bileşenlerini konu edinen farklı sınıf seviyelerine uygun kapsamlı testler geliştirmeleri önerilmektedir. 


\section{Kaynakça}

Akbay, M. (2015). Kurmacılık yaklaşımı ile dijital oyun ortamında tasarım yapmanın, lise öğrencilerinin geometri başarı, özyeterlilik ve uzamsal becerilerine etkisi (Yayınlanmamış yüksek lisans tezi). Atatürk Üniversitesi, Erzurum.

Alias, M., Black, T. R., \& Gray, D. E. (2002). Effect of instructions on spatial visualization ability in civil engineering students. International Education Journal, 3(1), 1-12.

Battista, M. T. (1990). Spatial visualization and gender differences in high school geometry. Journal for Research in Mathematics Education, 21 (3), 47-60.

Battista, M. T., Wheatley, G. H., \& Talsma, G. (1982). The importance of spatial visualization and cognitive development for geometry learning in preservice elementary teachers. Journal forResearch in Mathematics Education, 13, 332-340.

Baykul, Y., \& Güzeller C. O. (2014). Sosyal bilimler için istatistik: SPSS uygulamalı. Ankara: Pegem Akademi Yayıncılık.

Bayram, N. (2013). Yapısal eşitlik modellemesine giriş, AMOS uygulamaları. Bursa: Ezgi Kitabevi.

Bennett,G.K., Seashore, H.G., \& Wesman, A.G. (1974). The Differential Aptitude Tests (Form T). New York: The Psychological Corporation.

Bulut, S., \& Köroğlu, S. (2000). On birinci sınıf öğrencilerinin ve matematik öğretmen adaylarının uzamsal yeteneklerinin incelenmesi. Hacettepe Üniversitesi Eğitim Fakültesi Dergisi, 18, 56-61.

Büyüköztürk, Ş. (2011). Sosyal bilimler için veri analizi el kitabı. Ankara: Pegem Akademi Yayıncılık.

Büyüköztürk, Ş., Çokluk, Ö., \& Köklü, N. (2011). Sosyal bilimler için istatistik. Ankara: Pegem Akademi Yayıncılık.

Büyüköztürk, Ş., Kılıç Çakmak, E., Akgün, Ö. E., Karadeniz, Ş., \& Demirel, F. (2016). Bilimsel araştırma yöntemleri. Ankara: Pegem Akademi Yayıncilık.

Clements, D. H. (1998). Geometric and spatial thinking in young children. ERIC Document Reproduction Service No. ED 436232.

Clements, D. H., \& Battista, M. T. (1992). Geometry and spatial reasoning. D. A. Grouws (Ed.), In Handbook of research on mathematics teaching and learning (pp. 420-464). New York: Macmillan.

Clements, D. H., \& Sarama, J. (2011). Early childhood teacher education: The case of geometry. Journal of Mathematics Teacher Education, 14(2), 133-148.

Colom, R., Contreras, M., Shih, P. C., \& Santacreu, J. (2003). The assessment of spatial ability with a single computerized test. European Journal of Psychological Assessment, 19(2), 92-100.

Crandall, V. C., \& Lacey, B. W. (1972). Children's perceptions of internal-external control in intellectual-academic situations and their Embedded Figures Test performance. Child Development, 1123-1134.

Çokluk, Ö., Şekercioğlu, G., \& Büyüköztürk, Ş. (2012). Sosyal bilimler için çok değişkenli istatistik SPSS ve LiSREL uygulamaları (2.baskı). Ankara: Pegem Akademi Yayıncilık.

Delialioğlu, Ö. (1996). Contribution of students' logical thinking ability, mathematical skills and spatial ability on achievement in secondary school physics (Yayımlanmamış yüksek lisans tezi). Orta Doğu Teknik Üniversitesi, Ankara.

Diehl, C. piehl, C., \& Ranney, M. (1996). Assessing spatial navigation tools with instructional hypermedia for cognitive science. Proceedings of the Second International Conference on the Learning Sciences (pp. 36-43).

Dursun, Ö. (2010). The relationships among preservice teachers'spatial visualization ability, geometry self-efficacy, and spatial anxiety (Yayınlanmamış yüksek lisans tezi). Orta Doğu Üniversitesi, Ankara.

Ekstrom, R. B., Dermen, D., \& Harman, H. H. (1976). Manual for kit of factor-referenced cognitive tests (Vol. 102). Princeton, NJ: Educational Testing Service.

Erkek, Ö., Işıksal, M., \& Çakıroğlu, E. (2017). A study on pre-service teachers' spatial visualization ability and spatial anxiety. Kastamonu Education Journal, 25(1).

Fennema, E., \& Sherman, J. (1977). Sex-related differences in mathematics achievement, spatial visualization and affective factors. American educational research journal, 14(1), 51-71.

Freina, L., \& Ott, M. (2014). Discussing implementation choices for serious games supporting spatial and orientation skills. ICERI Proceedings, 5182-5191.

Friedman, L. (1995). The space factor in mathematics: Gender differences. Review of Educational Research, 65(1), 22-50.

Glück, J., Dünser, A., Steinbügl, K., \& Kaufmann, H. (2007). Warning: Subtle aspects of strategy assessment may affect correlations among spatial tests. Perceptual and Motor Skills, 104(1), 123-140.

Gorska, R., Sorby, S. A., \& Leopol, C. (1998). Gender differences in visualization skills-an international perspective. Engineering Design Graphics Journal, $62(3), 9-18$.

Gromko, J. E. (2004). Predictors of music sight-reading ability in high school wind players. Journal of research in music education, 52(1), 6-15.

Guay, R. B. (1976). Purdue Spatial Visualization Test. West Lafayette, Indiana: Purdue Research Foundation.

Gül, Ç. (2014). 8. Sınıf öğrencilerinin dönüşüm geometrisi başarıları ve uzamsal yeteneklerği arasındaki ilişkinin incelenmesi (Yayınlanmamış yüksek lisans tezi). Bülent Ecevit Üniversitesi, Zonguldak.

Hartman, N. W., \& Bertoline, G. R. (2005, July). Spatial abilities and virtual technologies: Examining the computer graphics learning environment. In Information Visualisation, Proceedings. Ninth International Conference, 992-997.

Holzinger, K. J., \& Swineford, F. (1946). The relation of two bi-factors to achievement in geometry and other subjects. Journal of Educational Psychology, 37, 257-265.

$\mathrm{Hu}$, L., \& Bentler, P. M. (1999). Cutoff criteria for fit indexes in covariance structure analysis: Conventional criteria versus new alternatives. Structural Equation Modeling, 6(1), 1-55. 
Jirout, J. J., \& Newcombe, N. S. (2014). Mazes and maps: Can young children find their way? Mind, Brain, and Education, 8(2), 89-96. Kan, A. (2011). Ölçme aracı geliştirme. S.Tekindal (Ed.), Eğitimde ölçme ve değerlendirme içinde (ss.239-276). Ankara: Pegem Akademi Yayıncilık.

Kayhan, E. B. (2005). Investigation of high school students" spatial ability. (Yayınlanmamış doktora tezi). Orta Doğu Teknik Üniversitesi, Ankara.

Kline, R. B. (2011). Principles and practice of structural equation modeling. New York: The Guilford Press.

Kösa, T. (2011). Ortaöğretim öğrencilerinin uzamsal becerilerinin incelenmesi (Yayınlanmamış doktora tezi). Karadeniz Teknik Üniversitesi, Trabzon.

Likert, R., \& Quasha, W. H. (1941). Revised Minnesota Paper Form Board. New York: Psychological Corporation

Linn, M. C., \& Petersen, A. C. (1985). Emergence and characterization of gender differences in spatial abilities: A meta-analysis. Child Development, 56, 1479-1498.

Lohman, D. F. (1979). Spatial ability: A review and reanalysis of the correlational literature. (Tecnical Report No.8). Aptitude Research Project, School of Education, Stanford University.

Lord, T. R., \& Rupert, J. L. (1995). Visual-spatial aptitude in elementary education majors in science and math tracks. Journal of Elementary Science Education, 7(2), 47-58.

Lorenz, C., \& Neisser, U. (1985). Factors of imagery and event recall. Memory \& Cognition, 13(6), 494-500.

Martín-Gutiérrez, J., Saorín, J. L., Martín-Dorta, N., \& Contero, M., (2009). Do video games improve spatial abilities of engineering students? International Journal of Engineering Education, 25(6), 1194-1204.

Mayer, R. E., \& Sims, V. K. (1994). For whom is a picture worth a thousand words? Extensions of a dual-coding theory of multimedia learning. Journal of educational psychology, 86(3), 389-401.

McGee, M. G. (1979). Human spatial abilities: Psychometric studies and environmental, genetic, hormonal, and neurological influences. Psychological Bulletin, 86(5), 889.

McKeever, W. F., \& Deyo, R. A. (1990). Testosterone, dihydrotestosterone, and spatial task performances of males. Bulletin of the Psychonomic Society, 28(4), 305-308.

Mix, K. S., \& Cheng, Y. L. (2012). The relation between space and math: Developmental and educational implications. J. B. Benson (Ed.), In Advances in child development and behavior. Burlington: Academic Press.

Miyake, A., Friedman, N. P., Rettinger, D. A., Shah, P., \& Hegarty, M. (2001). How are visuospatial working memory, executive functioning, and spatial abilities related? A latent-variable analysis. Journal of Experimental Psychology General, 130(4), 621- 640.

Mohler, J. L. (2006). Examining the spatial ability phenomenon from the student's perspective (Unpublished doctoral dissertation). Purdue University, Indiana.

Olkun, S. (2003). Comparing computer versus concrete manipulatives in learning 2D geometry. Journal of Computers in Mathematics and Science Teaching, 22(1), 43-56.

Olkun, S., \& Altun, A. (2003). İlköğretim öğrencilerinin bilgisayar deneyimleri ile uzamsal düşünme ve geometri başarıları arasındaki ilişki. The Turkish Online Journal of Educational Technology, 2(4), 86-91.

Olkun, S., Smith, G. G., Gerretson, H. P., Zembat, I. Ö., Erdem, A., \& Johnson, G. (2007). Sınıf öğretmeni adaylarının iki ve üç boyutlu uzamsal akıl yürütme becerilerinin uluslararası düzeyde karşılaştırılması. XVI. Ulusal Eğitim Bilimleri Kongresi, Gaziosmanpaşa Üniversitesi Eğitim Fakültesi, Tokat.

Pazzaglia, F., \& De Beni, R. (2001). Strategies of processing spatial information in survey and landmark-centred individuals. European Journal of Cognitive Psychology, 13(4), 493-508.

Pellegrino, J. W., Alderton, D. L., \& Shute, V. J. (1984). Understanding spatial ability. Educational Psychologist, 19 (4), $239-253$.

Petrusic, W. M., Varro, L., \& Jamieson, D. G. (1978). Mental rotation validation of two spatial ability tests. Psychological Research, 40(2), 139148.

Pittalis, M., \& Christou, C. (2010). Types of reasoning in 3D geometry thinking and their relation with spatial ability. Educational Studies in Mathematics, 75(2), 191-212.

Robichaux, R. L. R. (2000). The spatial visualization of undergraduates majoring in particular fields of study and the relationship of this ability to individual background characteristics (Unpublished doctoral dissertation). University of Auburn, Alabama.

Seçer, i. (2013). SPSS ve LISREL ile pratik veri analizi, analiz ve raporlaştırma. Ankara: Anı Yayıncılık.

Seçer, ì. (2015). Psikolojik test geliştirme ve uyarlama süreci, SPSS ve LISREL uygulamaları. Ankara: Anı Yayıncılık.

Senemoğlu, N. (2012). Gelişim, öğrenme ve öğretim, kuramdan uygulamaya. Ankara: Pegem Akademi.

Shamsuddin, N. A. A., \& Din, S. C. (2016). Spatial ability skills: A correlation between Augmented Reality (AR) and conventional way on wayfinding system. Environment-Behaviour Proceedings Journal, 1(2), 159-167.

Sharobeam, M. H. (2016). The variation in spatial visualization abilities of college male and female students in STEM fields versus non-STEM fields. Journal of College Science Teaching, 46(2), 93.

Shea, D. L., Lubinski, D., \& Benbow, C. P. (2001). Importance of assessing spatial ability in intellectually talented young adolescents: A 20-year longitudinal study. Journal of Educational Psychology, 93.

Shute, V. J., Pellegrino, J. W., Hubert, L., \& Reynolds, R. W. (1983). The relationship between androgen levels and human spatial abilities. Bulletin of the Psychonomic Society, 21(6), 465-468.

Şimşek, Ö. F. (2007). Yapısal eşitlik modellemesine giriş, temel ilkeler ve LiSREL uygulamaları. Ankara: Ekinoks Yayınları. 
Tekin, A. T. (2007). Dokuzuncu ve on birinci sınıf öğrencilerinin zihinde döndürme ve uzamsal görselleştirme yeteneklerinin karşılaştırmalı olarak incelenmesi (Yayımlanmamış yüksek lisans tezi). Ankara Üniversitesi, Ankara.

Tekin, H. (2010). Eğitimde ölçme ve değerlendirme. Ankara: Yargı Yayınevi.

Topaloğlu, i. (2011). Cabri 3d ile yapılan ders tasarımlarının öğrencilerin uzamsal görselleme ve başarılarına etkisinin incelenmesi (Yayınlanmamış yüksek lisans tezi). Marmara Üniversitesi, İstanbul.

Turgut, M., Yenilmez, K., \& Balbağ, M. Z. (2017). Öğretmen adaylarının mantıksal ve uzamsal düşünme becerileri: Bölüm, cinsiyet ve akademik performansın etkisi. Mehmet Akif Ersoy Üniversitesi Eğitim Fakültesi Dergisi, 1(41), 265-283.

Turğut, M. (2007). İlköğretim II. kademede öğrencilerin uzamsal yeteneklerinin incelenmesi (Yayımlanmamış yüksek lisans tezi). Dokuz Eylül Üniversitesi, İzmir.

Turğut, M. (2010). Teknoloji destekli lineer cebir öğretiminin ilköğretim matematik öğretmen adaylarının uzamsal yeteneklerine etkisi (Yayımlanmamış doktora tezi). Dokuz Eylül Üniversitesi, İzmir.

Turğut, M. (2015). Development of the spatial ability self-report scale (SASRS): Reliability and validity studies. Quality \& Quantity, 49(5), 19972014.

Turğut, M., \& Yılmaz, S. (2012). Illköğretim 7. ve 8. sınıf öğrencilerinin uzamsal yeteneklerinin incelenmesi. Dicle Üniversitesi Ziya Gökalp Eğitim Fakültesi Dergisi, 19, 69-79.

Urbina, S. (2004). Essentials of psychological testing. New Jersey: John Wiley \& Sons. Inc.

Uzun, N. (2013). Dinamik geometri yazılımlarının bilgisayar destekli öğretim ve akılı tahta ile zenginleştirilmiş öğrenme ortamlarında kullanımının öğrencilerin akademik başarısına, uzamsal görselleştirme becerisine ve uzamsal düşünme becerisine ilişkin tutumlarına etkisi (Yayınlanmamış yüksek lisans tezi). Gazi Üniversitesi, Ankara.

Wei, W., Yuan, H., Chen, C., \& Zhou, X. (2012). Cognitive correlates of performance in advanced mathematics. British Journal of Educational Psychology, 82, 157-181

Weisz, J. R., O'neill, P., \& O'neill, P. C. (1975). Field dependence-independence on the Children's Embedded Figures Test: Cognitive style or cognitive level?. Developmental Psychology, 11(4), 539.

Winter, J. W., Lappan, G., Fitzgerald, W., \& Shroyer, J. (1989). Middle Grades Mathematics Project: Spatial Visualization. NY: Addison-Wesley. Witkin, H. A. (1950). Individual differences in ease of perception of embedded figures. Journal of personality, 19(1), 1-15.

Yurt, E., \& Sünbül, A. M. (2014). Sekizinci sınıf öğrencilerinin matematik başarılarını açıklayan bir yapısal eşitlik modeli. Kuram ve Uygulamada Eğitim Bilimleri. 14(4), 1629-1623.

Yüksel, N. S., \& Bülbül, A. (2014). Uzamsal görselleştirme üzerine test geliştirme çalışması. Necatibey EğitimFakültesi Elektronik Fen ve Matematik Eğitimi Dergisi, 8(2), 124-142. 